


\title{
Review on Sensor Based Smart Alert System
}

\author{
Muskan Peerzade ${ }^{1}$, Alkiyasafeen $\mathrm{Khan}^{2}$, Vidya Ghadi ${ }^{3}$,Asmita Patil ${ }^{4}$ and Anand Gudnavar ${ }^{5}$ \\ Student, Dept of ECE, Maratha Mandal's Engineering College, Belagavi, Karnataka, India ${ }^{1}$ \\ Student, Dept of ECE, Maratha Mandal's Engineering College, Belagavi, Karnataka, India ${ }^{2}$ \\ Student, Dept of ECE, Maratha Mandal's Engineering College, Belagavi, Karnataka, India ${ }^{3}$ \\ Student, Dept of ECE, Maratha Mandal's Engineering College, Belagavi, Karnataka, India ${ }^{4}$ \\ Assistant Professor, Dept of ECE, Maratha Mandal's Engineering College, Belagavi , Karnataka, India ${ }^{5}$
}

\begin{abstract}
The Internet of things (IoT) has turned the way of implementation of most of the systems completely. Modern security systems with the implementation of cloud connectivity to the security devices .We analysed through the statistics data and we came across a significant percentage of people who go through harassment or other kind of abuse throughout the time respectively. In this digital era where all the basic works are done smoothly we believe that a security of the person should also be carried and implemented in with ease and smartness. As of today we face the problem of late in action towards these types of complaints in the system or we can say that there is a time bound for these kind of situations which is a critical situation for a person going through it, so to make it a quick fix. Based on the survey done on the existing system we propose to have a device which is the integration of multiple devices hardware comprises of a wearable or carrying smart system that endlessly communicates with sensible phone that has access to the web. This makes easy to track and communicate with the victim.
\end{abstract}

KEYWORDS: Internet of Things, Alert System, Smart Sensors.

\section{I.INTRODUCTION}

In Today's World the safety of women is in danger especially in India. The rate of crimes against women is not decreasing but in fact increasing at an alarming rate especially harassment, molestation, eve-teasing, sexual assault, kidnapping and domestic violence. Many preventive measures have been taken by the government to stop these misbehaving activities but still has not affected the growing rate of these crimes and has remained unaffected. The problem of sexual harassment in work place is increasingly coming out day- by-day. Sexual harassment at workplaces is unwanted behavior of a person that causes discomfort, offence or distress to the other. Majority of such cases are happened to woman by men working at high position in an organization. Women is getting kidnapped at every 44 minutes, sexually assault at every 47 minutes, 17 dowry deaths every day. The fear of harassment against women is not only the condition at outside but it may also happen at homes. Women are not so physically fit as compared to men so in case of a need a helping hand would be a boon for them.

Students face incidents like child trafficking and kidnapping, when they are waiting to embark or disembark a school bus. Loaded with security apps for women, your GSM can help you send emergency alerts to chosen people and also let people know about your whereabouts if anything goes wrong. Sometimes here might be a situation that when women had an accident in the late night and there are no one to help them, In such situations the person will not be able to tell the situation that he/she facing. And they do not know the basic first- aid details and to know the person where the incident has happened. Nowadays though there are many apps and devices evolved for women safety via smart phone which can be activated only by a touch or one click or shake the mobile.

\section{II.BACKGROUND}

This section discusses about the background of the study where the brief discussion is made for the existing ideas of safety alert system. We find that there are multiple research works, which have already briefed about the devices which have been made for the women safety. Therefore, we avoid repetitive discussion by highlighting only the less discussed points found in other studies. 


\section{III.THE PROBLEM}

The Problem identified in the existing system are as follow:

- Difficulty in the switching on of the devices manually.

- Tracking of the location becomes difficult.

- Issue with the recharging of the battery.

- Sudden response of the person nearer to the victim.

\section{IV.STUDIES ON RELATED WORK}

Table1. Summary of Related works:

1. The Comparison based on location detecting mechanism:

\begin{tabular}{|c|c|c|c|}
\hline Authors & Objective & Advantages & Limitations \\
\hline $\begin{array}{l}\text { Trupti Uday Prabhu } \\
\text { et al }\end{array}$ & $\begin{array}{l}\text { The main purpose of this } \\
\text { device is to intimate the } \\
\text { parents about the current } \\
\text { location of the women. }\end{array}$ & $\begin{array}{l}\text { The GPS signal is } \\
\text { available worldwide. } \\
\text { Therefore, users will } \\
\text { not be deprived of it } \\
\text { anywhere }\end{array}$ & $\begin{array}{l}\text { The GPS chip is hungry for } \\
\text { power and that drains the } \\
\text { battery in } 8 \text { to } 12 \text { hours. This } \\
\text { requires replacement or } \\
\text { recharge of the battery quite } \\
\text { frequently. }\end{array}$ \\
\hline $\begin{array}{l}\text { Poonam Sambhaji } \\
\text { Dhule, } \\
\text { Dr,S.D.Shirbahadur } \\
\text { kar }\end{array}$ & $\begin{array}{l}\text { A GPS system is used to } \\
\text { trace the current position } \\
\text { of the victim and a GSM } \\
\text { modem is used to send the } \\
\text { message to the pre-defined } \\
\text { numbers. }\end{array}$ & $\begin{array}{l}\text { The exact location of } \\
\text { the victim can be } \\
\text { obtained by using } \\
\text { gps-gsm module }\end{array}$ & $\begin{array}{l}\text { If the location of the victim is } \\
\text { changing rapidly then it's } \\
\text { difficult to find the current } \\
\text { location. }\end{array}$ \\
\hline
\end{tabular}


|| Volume 10, Issue 6, June 2021 ||

| DOI:10.15662/IJAREEIE.2021.1006057 |

\begin{tabular}{|l|l|l|l|}
\hline & & & \\
$\begin{array}{l}\text { Fleischer,P.B } ; \\
\begin{array}{l}\text { Nelson,A,Y and } \\
\text { more }\end{array}\end{array}$ & $\begin{array}{l}\text { To allow accurate } \\
\text { determination of } \\
\text { geographical locations by } \\
\text { military and civil users. }\end{array}$ & $\begin{array}{l}\text { GPS works altogether } \\
\text { weather so you would } \\
\text { like to not worry of } \\
\text { climate as in other } \\
\text { navigating devices }\end{array}$ & $\begin{array}{l}\text { GPS doesn't penetrate solid } \\
\text { walls or structures. it's also } \\
\text { suffering from large } \\
\text { constructions or structures. }\end{array}$ \\
\hline
\end{tabular}

2. The comparison based on communication detecting mechanism :

\begin{tabular}{|l|l|l|l|}
\hline Authors & Objective & Advantages & Limitations \\
\hline $\begin{array}{l}\text { D. G. Monisha; M. } \\
\text { Monish and more }\end{array}$ & $\begin{array}{l}\text { The GSM modem sends an } \\
\text { SMS to the pre-defined } \\
\text { mobile number. }\end{array}$ & $\begin{array}{l}\text { Provides an update } \\
\text { with location to the } \\
\text { respective members. }\end{array}$ & $\begin{array}{l}\text { All the existing systems must } \\
\text { be connected to the } \\
\text { GPRS service to work } \\
\text { properly, hence cannot be } \\
\text { used during emergency if } \\
\text { there is no internet } \\
\text { connectivity. }\end{array}$ \\
\hline Vivekanad Mishra & Encryption for phone calls. & $\begin{array}{l}\text { GSM is the same } \\
\text { network worldwide, } \\
\text { users are not charged a } \\
\text { international calls }\end{array}$ & $\begin{array}{l}\text { Multiple users share the same } \\
\text { bandwidth. With enough } \\
\text { users, the transmission can } \\
\text { encounter interference. }\end{array}$ \\
\hline
\end{tabular}


|| Volume 10, Issue 6, June 2021 ||

| DOI:10.15662/IJAREEIE.2021.1006057 |

\begin{tabular}{|c|c|c|c|}
\hline $\begin{array}{l}\text { Masum Bakaul; } \\
\text { H.M.Abdul Ah and } \\
\text { more }\end{array}$ & $\begin{array}{l}\text { Precise security measures } \\
\text { some of which maintains } \\
\text { privacy and confidentiality of } \\
\text { users' identity and data while } \\
\text { others ensure that only } \\
\text { registered users access the } \\
\text { network. }\end{array}$ & $\begin{array}{l}\text { Real-Time Protection } \\
\text { Against Mobile Cyber } \\
\text { Threats. A mobile } \\
\text { security solution } \\
\text { provides your device } \\
24 / 7 \text { protection }\end{array}$ & $\begin{array}{l}\text { Security is not implemented } \\
\text { only in fixed part }\end{array}$ \\
\hline
\end{tabular}

3 .The comparison based on detection of physical properties:

\begin{tabular}{|l|l|l|l|}
\hline Authors & Objective & Advantages & Limitations \\
\hline $\begin{array}{l}\text { Sanjana Babdi; } \\
\text { Janhavi Jathar; and } \\
\text { more }\end{array}$ & $\begin{array}{l}\text { IR sensors are used in } \\
\text { radiation thermometers to } \\
\text { measure the temperature } \\
\text { depend upon the temperature } \\
\text { and the material of the object }\end{array}$ & $\begin{array}{l}\text { Do not need contact } \\
\text { with the object for } \\
\text { detection }\end{array}$ & $\begin{array}{l}\text { These can be affected by fog, } \\
\text { rain, dust, etc. }\end{array}$ \\
\hline $\begin{array}{l}\text { Nikos. E. } \\
\text { Mastorakis }\end{array}$ & $\begin{array}{l}\text { gas analyzers that use the } \\
\text { absorption characteristics of } \\
\text { gases in the IR region }\end{array}$ & $\begin{array}{l}\text { Monitoring emission } \\
\text { levels over longer } \\
\text { periods of time. }\end{array}$ & $\begin{array}{l}\text { A simple measurement } \\
\text { becomes a complex } \\
\text { measurement }\end{array}$ \\
\hline $\begin{array}{l}\text { M.Tejaswini; } \\
\text { Mr.K.Shiva Kumar }\end{array}$ & $\begin{array}{l}\text { Detection of abnormal } \\
\text { variation in the environment. }\end{array}$ & $\begin{array}{l}\text { Infrared movement } \\
\text { sensors identify } \\
\text { movement in daytime } \\
\text { and evening } \\
\text { dependably. }\end{array}$ & $\begin{array}{l}\text { Sometimes unwanted } \\
\text { detection may occur }\end{array}$ \\
\hline & & & \\
\hline
\end{tabular}




\section{WOMEN'S APP}

The comparison table for various apps are determined such as senses the location, record audio automatically, and alert sound will be sent to their saved contacts

Safetipin: It is a personal app for safety that helps user to take safer decisions, a safety score is provided for each area , based on the safety score of an area. The location is termed as safe or unsafe. When user enters an unsafe location, it alerts them to a warning message, as long as the application is in the background, a user can also invite their friend and family to track their location. This app also provides alternate route to the destination; the user can check the safety and choose the route based on it.

Life360: It is a family locator mobile application enables the user to share location with their family members .The user can create a group with their friends and Family members; it alert the user when the group members come near them, this app also helps in emergency situations for girls when they are in danger situation, it sends the location to the group members.

Vithu: This mobile application is used to alert the women's guardians when she is in danger by pressing the buzzer button for twice, this process initiates a cycle that sends the location of the mobile to the designated contacts for every 2 minutes. The location is sent in SMS(short message service). This application also provides updates of crime scene happened in India with tips feed those update scan also be done by the user of this application.

Table 2: Summary of Existing Ideas:

\begin{tabular}{|l|l|l|l|}
\hline Authors & Objective & Advantages & Limitations \\
\hline B.Vijayalakshmi & $\begin{array}{l}\text { To improve the women } \\
\text { safety by using GPS } \\
\text { and GSM }\end{array}$ & $\begin{array}{l}\text { Safety device carried by everyone. } \\
\text { Low cost. } \\
\text { Small size device }\end{array}$ & $\begin{array}{l}\text { In panic mode, if she } \\
\text { does not press the } \\
\text { buzzer, The location } \\
\text { can't be identified. }\end{array}$ \\
\hline Humgnguyen & $\begin{array}{l}\text { To observe and detect } \\
\text { the person, In daily life } \\
\text { with PD and give } \\
\text { treatment based on that }\end{array}$ & $\begin{array}{l}\text { To identify the disease in short } \\
\text { time. } \\
\text { From free environment, we can } \\
\text { observe the illness and take } \\
\text { treatment for that }\end{array}$ & $\begin{array}{l}\text { The measuring device } \\
\text { fixed in objects. If the } \\
\text { person away from the } \\
\text { object.IT can't be } \\
\text { predicted }\end{array}$ \\
\hline
\end{tabular}


|| Volume 10, Issue 6, June 2021 ||

| DOI:10.15662/IJAREEIE.2021.1006057 |

\begin{tabular}{|c|c|c|c|}
\hline Mr.Amar Saraswat & $\begin{array}{l}\text { To sense and monitor } \\
\text { the heartbeat and body } \\
\text { temperature using } \\
\text { Arduino }\end{array}$ & $\begin{array}{l}\text { It is used to measure mean arterial } \\
\text { pressure in one minute. } \\
\text { It is used to measure physiological } \\
\text { parameters. }\end{array}$ & $\begin{array}{l}\text { The result will be } \\
\text { displayed on LCD } \\
\text { screen if the screen is } \\
\text { not there it can't be } \\
\text { measured. }\end{array}$ \\
\hline A.H.Ansari & $\begin{array}{l}\text { To monitor the women } \\
\text { security by using GPS } \\
\text { and GSM system }\end{array}$ & $\begin{array}{l}\text { The device is small, and it can } \\
\text { carry to anywhere. } \\
\text { Low cost. } \\
\text { Performance high. } \\
\text { Eco-friendly. }\end{array}$ & $\begin{array}{l}\text { If the buzzer is not } \\
\text { pressed. It won't work } \\
\text { the process. }\end{array}$ \\
\hline Charranzhou & $\begin{array}{l}\text { To find the trip end } \\
\text { whil travelling or not } \\
\text { travelling by using the } \\
\text { smart-phones based on } \\
\text { GPS tracking system. }\end{array}$ & $\begin{array}{l}\text { Using data driven machine } \\
\text { language to find the } 96 \% \text { of points } \\
\text { are identified in trip ends. }\end{array}$ & $\begin{array}{l}\text { It takes so many days } \\
\text { to find the result. }\end{array}$ \\
\hline Yanbozhao & $\begin{array}{l}\text { To design the home } \\
\text { security system at a } \\
\text { low cost GSM/GPRS } \\
\text { system. }\end{array}$ & $\begin{array}{l}\text { It is user friendly interface. } \\
\text { Response rapidly to any incident } \\
\text { occurs. } \\
\text { Reduce power consumption. }\end{array}$ & $\begin{array}{l}\text { Cost is high. } \\
\text { Security is }\end{array}$ \\
\hline HasmahMansor & $\begin{array}{l}\text { To monitor the body } \\
\text { temperature using the } \\
\text { remote system. }\end{array}$ & $\begin{array}{l}\text { If the patient is not well that } \\
\text { details will be transmitted to the } \\
\text { doctor based on that doctor gives } \\
\text { treatment to that patient. } \\
\text { It saves the hospital bill.It reduces } \\
\text { the waiting time in the hospital. }\end{array}$ & $\begin{array}{l}\text { If the is no internet } \\
\text { connectio, the details } \\
\text { of the patient cannot be } \\
\text { received by the doctor. }\end{array}$ \\
\hline JG Lourens & $\begin{array}{l}\text { Detection and logging } \\
\text { advertisements using its } \\
\text { sound. }\end{array}$ & $\begin{array}{l}\text { Pattern matching approach and } \\
\text { Time wrapping sensitivity. }\end{array}$ & $\begin{array}{l}\text { Change in the } \\
\text { frequency the response } \\
\text { of the channel } \\
\text { Distortion and noise } \\
\text { problem. }\end{array}$ \\
\hline
\end{tabular}


| DOI:10.15662/IJAREEIE.2021.1006057 |

\section{VI.RESEARCH GAP}

In the surveyed made on the existing systems the device/application can be made better and the usage can be increased by making the product small so that it can be used as a watch or even a pendent and also there can be a voice keyword recognition which can trigger the device to send an emergency message to the preset contacts. The device can be made more helpful by adding any defence element in the device in order to protect oneself if the help gets delayed, as a backup option. The device has many advantages but at the same time it has many disadvantages too. The battery consumption will be extremely high so if there is any battery backup option it will be more efficient. The proposed device is portable which has SMS options, screaming sensors and also defence element, thereby covering almost all needs. It can be more helpful by adding few more sensors like pressure sensors and detecting hidden cameras. The device can be made more useful by adding any alarm to alert the victim's surrounding areas as rapid protection can be given to the victim as Internet cannot be relied on all the time. The device can be made more effective by adding recording system in order to record the incident taking place which in turn can help get justice to the victim or even add sensors to activate the device automatically when in danger. In addition to all the features present there can also be a defense element which helps women to deal with the threat not completely rely for other to come and rescue her. The smart band should also be able to produce an alarm or buzzer sound so that it can be used to get public attention and the people can contribute in providing justice .Instead of sending the instant location of the victim a real time location can be shared to respective people as victim will be in panic and there is more chance of running which will lead to missing of the victim. These were the new ideas which were not generally seen, but the major disadvantage of the proposed model is cost and implementing all the ideas into one system will cut down the pocket and increase the size of the system which makes it as non-portal device.

\section{VII.CONCLUSION}

Based on the survey on existing systems present for the women security we conclude that in past few years with the growing technologies many devices for the women safety has been made but there were some loopholes with the devices. This paper attempts to discuss the women security devices and aims to reduce the loopholes by comparing the existing devices.

\section{REFERENCES}

[1].S. A. More, R. D. Borate, S. T . Dardige, S. S. Salekar, Prof. D. S.Gogawale "Smart Band for Women Security Based on Internet of T hings (IOT)" International Journal of Advance Research in Scienceand Engineering, Volume No 6,Issue No. 11, November 2017

[2]. Mohamad Zikriya, Parmeshwar M G, Shanmukayya R Math, ShraddhaT ankasali, Dr. Jayashree D Mallapur "Smart Gadget for Women Safetyusing IoT (Internet of Things)" International Journal of EngineeringResearch \& Technology (IJERT ), ISSN: 2278-0181, NCESC - 2018 Conference Proceedings

[3]. Naeemul Islam, Md. Anisuzzaman, Sikder Sunbeam Islam, Mohammed Rabiul Hossain, Abu Jafar Mohammad Obaidullah "Design and Implementation of Women Auspice System by Utilizing GPS and GSM". 2019 International Conference on Electrical, Computer and Communication Engineering (ECCE), 7-9 February, 2019

[4].Borges,L.M. Inst. de Telecomun.-DEM, Univ. da Beira Interior,Covilha, Portugal Barroca, N. ; Velez, F.J. ; Lebres, A.S., Smart- clothing wireless flex sensor belt network for foetal health monitoring; Pervasive Computing Technologies for Healthcare, 2009. PervasiveHealth 2009. , IEEE, London.

[5].Rana, G.M.S.M.; Khan,A.A.M; Hoque,M.N.; Mitul,A.F. Design and implementation of a GSM based remote home security and appliance control system; Advances in Electrical Engineering (ICAEE),2013 Control System ,IEEE Conference Dhaka.

[6].Rahdar, R. ; Bell Helicopter, Fort Worth, TX, USA ; Stracener, J.T.Olinick, E.V.; A Systems Engineering Approach to Improving the Accuracyof Mobile Station Location Estimation; Systems Journal, IEEE (Volume:8 ,Issue: $1,2013)$

[7]. Vijaylashmi, B., Renuka, S., Chennur, P., \&Patil, S. (2015). Self-defense system for women safety with location tracking and SMS alerting through GSM network. International Journal of Research in Engineering and Technology (IJRET), 4(5).

[8]. Deepak Sharma, Abhijit Paradkar "All in one Intelligent Safety Systemfor Women Security". Vol 130 No.11 November 2015.

[9].Prof. R.A. Jain, Aditya Patil, Prasenjeet Nikam, Shubham More, Saurabh Totewar,” Women's safety using IOT “. 
|| Volume 10, Issue 6, June 2021 ||

| DOI:10.15662/IJAREEIE.2021.1006057 |

Vol: 04 Issue: 05|May-2017

[10].Strauss, Marc D. HandWave: design and manufacture of a wearablewireless skin conductance sensor and housing. Diss. MassachusettsInstitute of Technology,

[11].S. Lee, K. Mase, "Activity and location recognition using wearable sensors", IEEE Pervasive Computing, pp. 2432, 2002. 
